\title{
IPTEKS PROSEDUR PENILAIAN ASET TETAP PADA KANTOR PELAYANAN KEKAYAAN NEGARA DAN LELANG (KPKNL) MANADO
}

\author{
Juniarti Melisa Maruf $^{1}$, Elisabeth Tampang ${ }^{2}$, Stanley Kho Walandouw ${ }^{3}$ \\ 1,2,3 Jurusan Akuntansi, Fakultas Ekonomi dan Bisnis Universitas Sam Ratulangi, Jl. Kampus Unsrat, Manado, \\ 95115, Indonesia \\ E-mail : Melichamaruf09@gmail.com
}

\begin{abstract}
Fixed assets are tangible assets to be owned or used in the production, supply of goods or services. Aim to administer and be used for more than one period. In this material there is a procedure where as a stage of activity activities to solve it and steps to resolve a problem. Assessment is the process of activities to provide value opinions on objects of valuation in the form of State Property. Fixed Assets consist of two types, namely tangible fixed assets and intangible fixed assets. The purpose of this study was to analyze the procedure for assessing fixed assets at KPKNL Manado. The method used is an analysis of the valuation of the fixed assets of KPKNL Manado. The results of the study are in accordance with the existing reports, still collecting some background information, clear requests, objectives for assessment and description of the object of assessment.
\end{abstract}

Keywrods: Procedure, Assessment, Fixed Assets

\section{PENDAHULUAN}

Barang Milik Negara merupakan Aset Tetap yang bisa berwujud atau tidak berwujud dengan masa manfaatnya lebih dari satu tahun yang bisa kita lihat dalam Standar Akuntansi Pemerintahan (SAP). Barang Milik Negara bisa berupa tanah, bangunan, jalan, irigasi, kendaraan bermotor dan konstruksi dalam pekerjaan. Semuanya ini bisa diperoleh melalui sumbangan dari luar pemerintah pusat, kontrak kerja sama yang sudah disepakati, dan diperoleh dari hasil keputusan pengadilan yang sudah lolos uji kekuatan hukum yang tetap. Sebelum semua barang milik negara ini digunakan untuk kegiatan operasional pemerintahan maka harus dilakukan prosedur penilaian aset tetap terlebih dahulu. Penilaian biasanya dilakukan oleh seksi penilaian KPKNL Manado. Penilaian adalah proses dari kegiatan yang dilakukan untuk memberikan opini nilai dari objek penilaian terhadap barang milik negara. Data informasi yang di dapatkan oleh seksi penilaian diperoleh dari surat permohonan penilaian barang miik negara yang diajukan langsung oleh pihak yang bersangkutan dan akan diurus oleh tim penilaian dengan melakukan pemeriksaan langsung ke lokasi objek.

Berdasarkan dari penemuan data yang penulis peroleh dari bagian Seksi Penilaian Kantor Pelayanan Kekayaan Negara dan Lelang di Manado, penulis menemukan masalah dari penilaian KPKNL Manado tentang Barang Milik Negara yaitu perbedaan penyesuaian luas tanah pada kertas kerja penilaian aset tetap. Penyeselaian dari masalah tersebut harus dilakukan dengan metodologi penilaian untuk menentukan plus minus dan mekanisme verifikasi terhadap laporan penilaian aset tetap. Tujuannya untuk mempermudah tim penilaian melakukan pemeriksaan barang milik Negara, ketika berada di objek penilaian.

\section{TINJAUAN PUSTAKA}

Pengertian Prosedur. Prosedur berasal dari bahasa inggris yaitu "procedur" yang artinya suatu cara atau langkah-langkah dalam menyelesaikan pekerjaan yang dilakukan. Prosedur biasanya juga digunakan untuk menyelesaikan masalah yang sedang terjadi baik diinstansi pekerjaan maupun dalam kehidupan pribadi. Prosedur penilaian aset tetap bisa 
digunakan melalui pendekatan pasar dimana data yang ada harus dilakukan perbandingan atas aset yang dinilai, juga perlu mengungkapkan karakteristik aset maupun data yang mirip dengan aset pembanding yang dinilai.

Pengertian Penilaian. Penilaian adalah alat untuk mengukur kinerja dari pegawai dalam menyelesaikan tugas pekerjaan yang diberikan. Penilaian biasanya juga digunakan dalam dunia pendidikan untuk memberikan nilai kepada para siswa-siswi atas kerja keras mereka selama belajar. Penilaian juga bisa digunakan dalam kehidupan sehari-hari, seperti menilai sifat dan karakter dari seseorang yang baru kita temui, untuk bisa mengetahui kepribadian dirinya.

Pengertian Aset Tetap. Aset tetap adalah aset yang memiliki umur panjang lebih dari satu tahun. Aset tetap merupakan peranan penting karena memiliki nilai yang cukup signifikan bila dibandingkan yang lain. Aset tetap terbagi atas dua jenis yaitu aset tetap yang berumur tidak terbatas yang biasanya tidak dikelola seperti tanah tetapi dapat dibuat bangunan dan lapangan olahraga dan nilai jualnya semakin hari semakin naik dan aset tetap yang miliki umur ekonomi, aset ini memiliki umur yang terbatas karena masa manfaatnya tidak bisa bertahan terlalu lama, aset tetap ini dapat berupa bangunan, peralatan dan mesin dan nilai jualnya pun bisa semakin menurun tergantung dari kondisi fisik aset tersebut.

\section{METODE PENERAPAN IPTEKS}

\subsection{Metode Penerapan Ipteks}

Metode penerapan ipteks yang digunakan yaitu deskriptif data, metode ini bertujuan untuk mengungkapkan gambaran situasi dan keadaan yang sedang terjadi dalam seksi penilaian KPKNL Manado.

\subsection{Teknik Penerapan Ipteks}

Teknik Penerapan ipteks yaitu mengumpulkan data-data penilaian Barang Milik Negara. Dengan cara mewawancarai kepala seksi penilaian KPKNL manado tentang prosedur penilaian aset tetap yang digunakan untuk menilai objek penilaian.

\section{PEMBAHASAN}

\subsection{Gambaran Objek Penerapan Ipteks}

Kantor Pelayanan Kekayaan Negara dan Lelang (KPKNL) Manado merupakan instansi vertical Direktorat Jenderal Kekayaan Negara (DJKN) yang berada di bawah departemen keuangan RI dan harus bertanggungjawab kepada ( Kepala Kantor wilayah, Dierektorat Jenderal Kekayaan Negara Sulut, Sulteng, Gorontalo, dan Maluku utara). Kantor Pelayanan kekayaan Negara dan Lelang Manado beralamatkan di Jl.Bethesda No 6-8 Manado dan terletak di Gedung Keuangan Negara Lt IV. KPKNL Manado merupakan kantor yang memberikan pelayanan berupa pelayanan piutang negara, pelayanan lelang, pelayanan peengelolaan kekayaan negara dan pelayanan penilaian, visi dari KPKNL manado yaitu menjadi pengelola KPKNL yang profesional dan bertanggungjawab demi kemakmuran rakyat, masing-masing dari setiap seksi ini memiliki tugas dan fungsi yang berbeda-beda terutama pada seksi penilaian. Seksi penilaian ini memiliki tugas untuk memberikan penilaian terhadap aset tetap Barang Milik Negara. Tujuan dilakukan penilaian yaitu untuk pemanfaatan, pemindatangaan, penyusunan laporan penilaian dan pelaksanaan kegiatan lain sesuai dengan kententuan peraturan perundang-undangan.

\subsection{Pembahasan}

Untuk dilakukan penilaian aset tetap pada KPKNL Manado harus mengikuti beberapa langkah atau proses yaitu:

Tim Penilai. Sebelum terjun ke lapangan untuk melakukan survei harus dibentuk tim untuk melakukan penilaian, tim penilai ini ditetapkan dengan keputusan Direktur yang memiliki tugas dan fungsi dibidang penilaian pada Direktorat Jenderal dan yang menetapkan 
keputusan dikantor pelayanan adalah kepala kantor pelayanan. Jumlah anggota tim penilai harus ganjil dan sekurang-kurangnya 3 anggota, satu berkedudukan sebagai ketua dan dua sebagai anggota, untuk menjadi ketua harus dari penilai Direktorat Jenderal dan anggota penilai harus dari pegawai yang bisa diandalkan dalam ketepatan bekerja,rapih dan pintar dalam melakukan tugas yang diberikan sehingga bisa menjadi tim penilai Direktorat Jenderal. Kurangnya sumber daya manusia sering kali menjadi kesulitan dalam teknis untuk melakukan penilaian.

Analisis permohonan nilai dan verifikasi. Analisis permohonan nilai sangat dibutuhkan untuk mengetahui kelengkapan data agar mempermudah tim penilai untuk melakukan penilaian serta mempermudah dalam penyusunan laporan penilaian. Ketika melakukan analisis permohonan nilai dan verifikasi harus dibutuhkan ketelitian dalam pemeriksaan data apakah sudah lengkap atau belum, karena sering terjadi kendala ketika tim penilai sudah terjun ke lokasi survei untuk melalakukan penilaian data yang diperoleh sering kali belum lengkap dan kurang jelas sumber informasinya. Jika hal ini terjadi maka tim penilai akan membuat surat permintaan kelengkapan data kepada pemohon dan memberikan waktu 15 hari untukmelengkapi data yang belum ada untuk dilengkapai,apabila dalam waktu 15 hari kelengkapan data belum lengkap maka tim penilai akan mengembalikan permohonan penilaian kepada pihak pemohon dan tim penilaian akan menghentikan proses penilaian dan tidak perlu dilanjutkan lagi serta data yang diberikan akan dikembalikan semua kepada pemohon. Data dan informasi yang didapatkan baik dari pihak pemohon, basis data penilaian, hasil dari survey lapangan semua digunakan untuk proses analisis. Faktor yang perlu dipertimbangkan dalam analisis objek penilaian ada dua yang pertama tanah. Tanah, harus meliputi : objek lokasi, luas, bentuk, ukuran, jenis, kontur, elevasi, fasilitas umum yang tersedia, peruntukan area (zoning), perizinan dari pemerintah, dokumen kepemilikan, dan faktor lain yang terikat. Sedangkan Bangunan, harus meliputi : tahun kapan selesai dibangun, tahun bangunan di renovasi atau restorasi, konstruksi dan material yang dipakai, luas bangunan, bentuk bangunan, tinggi dari bangunan tersebut, jumlah lantai yang ada, kondisi bangunan secara keseluruhan, sarana pelengkap yang ada, penggunaan bangunan, dan faktor lain yang terkait.

Survey Lapangan. Untuk menyusun laporan penilaian maka tim penilai harus melakukan survey lapangan, tujuan untuk dilakukan survey lapangan yaitu mengindentifikasi objek penilai atau objek pembanding, meneliti kondisi fisik lapangan apakah sesuai untuk mengumpulkan data awal. Tim penilai harus terjun langsung ke lokasi survey untuk menilai objek apakah sesuai dengan permohonan penilaian yang diberikan pemohon atau tidak. Survey lapangan harus dilakukan sampai selesai oleh tim penilai dan tidak terikat oleh waktu untuk dilakukan penilaian sampai tim penilai mendapatkan data yang dibutuhkan, tim penilai harus mengumpulkan sebanyak mungkin informasi seputar objek penilaian, mencocokkan kebenaran data awal dengan ada yang dilapangan apakah cocok atau ada yang tidak cocok dengan data yang diberikan. Dalam melakukan servey lapangan banyak kendala yang dihadapi oleh tim penilai seperti lokasi objek penilaian susah untuk dilewati baik di darat maupun laut sehingga tim penilai seringkali harus berjalan kaki sejauh mungkin, kesulitan jaringan untuk berkomunikasi ketika berada didalam pedalaman, data yang sudah dibawa ketika di survey lapangan kurang jelas dan lengkap tentang keterangan yang harus dilakukan penilaian. Objek penilaian ada dua jenis yang pertama penilaian terhadap tanah, penilaian tanah ini harus memiliki infromasi data meliputi: perencanaan tata ruang wilayah, keterangan harga, informasi pengganti rugi atas pengadaan tanah untuk kepentingan umum, data penjualan harga barang secara lelang, dan infromasi harga transaksi dan penawaran. Penilaian kedua terhadap bangunan,harus memiliki informasi data meliputi: Denah konstruksi bangunan, spesifikasi bangunan secara keseluruhan, deskripsi fisik bangunan, tahun kapan 
selesai dibangun dan tahun renovasi atau restorasi, data strandar harga satuan bangunan, dan rencana tata ruang wilayah atau rencana detail tata ruang.

Penyusunan Laporan Penilaian. Dalam penyusunan laporan penilaian dibutuhkan semua kelengkapan data yang diperoleh oleh tim penilaian ketika melakukan survey lapangan, hal ini bertujuan agar ketika penyusunan laporan penilaian dibuat mempermudah pihak yang bertugas untuk membuat laporan penilaian menjadi mudah. Penyusunan laporan penilaian dilakukan didalam kantor pelayanan kekayaan negara dan lelang dan diawasi langsung oleh ketua tim penilaian. Penyusunan laporan penilaian harus dibutuhkan kerja sama dan ketelitian antar tim, untuk mempermudah mengelola data yang diperoleh dari lapangan apakah sesuai dengan kondisi yang ada dilapangan dengan data yang diberikan oleh pemohon, hal ini bertujuan untuk mempermudah salinan koreksi kepada tim penilaian agar lebih teliti dan cekatan lagi ketika melakukan penilaian di lapangan.

\section{KESIMPULAN DAN SARAN}

\subsection{Kesimpulan}

Proses prosedur penilaian aset tetap pada Kantor Pelayanan Kekayaan Negara dan Lelang Manado sudah dilakukan sesuai prosedur yang semestinya dan tetap mengikuti aturan yang sudah dibuat oleh pemerintah lewat peraturan perundang-undangan. Dari hasil yang kami dapat prosedur penilaian aset tetap yaitu dibentuknya tim penilai untuk bisa terjun ke lapangan. Untuk mensurvey objek penilaian dengan menggunakan analisis permohonan nilai dan verifikasi agar bisa dilakukan proses penilaian aset tetap dan dapat menyusun laporan penilaian.

\subsection{Saran}

Agar prosedur penilaian bisa berjalan dengan lancar diharapkan kepada pemohon yang ingin melakukan penilaian barang milik negara untuk bisa mengecek kelengkapan data ketika datang ke kantor KPKNL,hal ini bertujuan supaya proses yang dibutuhkan tidak terlalu lama dan tidak menyusahkan para tim yang sedang mengsurvey objek penilaian dilapangan.

\section{DAFTAR PUSTAKA}

Akuntansi dan Manajemen. 2018. "Pengertian Aktiva Tetapatau Asset Tetap". Diakses Pada Tanggal 3 November 2018.

Maruli.Dmk. 2017. "Pengertian Prosedur". Diakses pada tgl 3 November 2018.

Kolega Media. 2008. "KPKNL-Hanya Segelintir Orang Yang Tahu”.

Diakses Pada Tanggal 10 November 2018.

Fadjarwati N. 2011. "Pengertian Penilaian Kinerja".

Pada Tanggal 4 November 2018.

KeuanganLSM. 2018. ”Aset tetap". Diakses Pada Tanggal 28 november 2018.

Pasaribut Mangihot. 2016. "Definisidan Klasifikasi Aset Tetap". Diakses Pada Tanggal 28 November 2018.

Kementrian Keuangan Republik Indonesia. 2009. Peraturan Mentri Keuangan Republik Indonesia Nomor 179/PMK.06/2009. Tentang Penilaian Milik Negara.

Kementrian Keuangan Republik Indonesia. 2017. Peraturan Mentri Keuangan Republik Indonesia Nomor 111/PMK.06/2017. Tentang Penilaian Objek Barang Milik Negara.

Presiden Republik Indonesia. 2017. Peraturan Pemerintah Republik Indonesia Nomor 71 tahun 2017. Tentang Standar Akuntansi Pemerintahan (SAP).

Kementrian Keuangan Republik Indonesia. 2017. Peraturan Direktur Jendral Kekayaan Negara Nomor 7/KN/2017. Tentang Pedoman Pelaksanaan Penilaian Barang Milik Negara. 
Presiden Republik Indonesia. 2014. Peraturan Pemerintah Republik Indonesia Nomor 27 Tahun 2014. Tentang Pengelolaan Barang Milik Negara.

Kementrian Keuangan Republik Indonesia. 2016. Keputusan Direktur Jendral Kekayaan Negara. Nomor 124/KN/2016. Tentang Standar Pelaporan Penilaian.

KPKNL Manado. ’Penilaian Barang Milik Negara". 2018. 